\title{
EKSISTENSI KEWENANGAN DEWAN PERWAKILAN DAERAH DALAM MELAKUKAN PEMANTAUAN DAN EVALUASI RANCANGAN PERATURAN DAERAH DAN PERATURAN DAERAH BERDASARKAN UNDANG-UNDANG NOMOR 2 TAHUN 2018 TENTANG MPR, DPR, DPD DAN DPRD
}

\author{
Imelda Sapitri \\ LSM Wahana Lingkungan hidup Indonesia Wilayah provinsi Riau \\ Email : Imelda932016@gmail.com
}

\begin{abstract}
Abstrack
This article discusses the authority of the regional representative councils in the monitoring and evaluating draft regional regulations and regional regulations. The Regional Representative Council only has the authority to judge regional regulations that countradict highher laws, public interests and decency but do not have the authority to issue decisions regarding the cancellation of regional regulations. The new authority is in the form of recommendations. This recommendation was given to the reginal legislative assembly and regional heads and recommendations were also given to non-governmental organization to conduct a judicial review to the Supreme Court.

Keywords: The Regional Representative Council, Recommendation, Local Regulation
\end{abstract}

\begin{abstract}
Abstrak
Artikel ini membahas kewenangan Dewan Perwakilan Daerah dalam melakukan pemantauan dan evaluasi rancangan peraturan daerah dan peraturan daerah. Dewan Perwakilan Daerah hanya berwenang untuk menilai peraturan daerah bertentangan dengan peraturan perundangundang yang lebih tinggi, kepentingan umum serta kesusilaan namun tidak memiliki kewenangan untuk mengeluarkan keputusan terkait pembatalan peraturan daerah. Adapun kewenangan baru ini berupa rekomendasi. Rekomendasi ini diberikan kepada Dewan Perwakilan Rakyat Daerah dan Kepala Daerah serta rekomendasi juga diberikan kepada Lembaga Swadaya Masyarakat untuk melakukan Judicial Review ke Mahkamah Agung.

Kata kunci: Dewan Perwakilan Daerah, Rekomendasi, Peraturan Daerah
\end{abstract}




\section{PENDAHULUAN \\ Latar Belakang}

Lembaga Negara muncul dari mengejawantahkan konsep "Trias Politica" sebagai representasi pembagian kekuasaan. Hubungan antar lembaga Negara tersebut akan membentuk sistem Pemerintahan. Bintan R. Saragih menyebutkan sistem Pemerintahan sebagai susunan dan tatanan dari keseluruhan yang teratur dari lembaga-lembaga Negara yang berkaitan antara satu dengan yang lainnya baik secara langsung maupun tidak langsung untuk mencapai pola menurut rencana atau tujuan Negara. ${ }^{1}$

Lembaga Negara yang diatur dan dibentuk oleh Undang-undang Dasar merupakan organ konstitusi, sedangkan yang dibentuk berdasarkan Undang-undang merupakan organ undang-undang, sementara yang hanya dibentuk karena keputusan Presiden tentunya lebih rendah lagi tingkatan dan derajat perlakuan hukum terhadap pejabat yang duduk didalamnya. Demikian pula jika lembaga di maksud dibentuk dan diberi kekuasaan berdasarkan peraturan daerah tentu lebih rendah lagi tingkatannya.

DPD adalah salah satu lembaga negara yang kewenangannya diatur dalam Undang-Undang Dasar Negara Republik Indonesia. DPD lahir pada tanggal 1 Oktober 2004 merupakan hasil dari perdebatanperdebatan fraksi-fraksi yang pada saat itu anggotanya hanya berjumlah 128 orang yang dilantik kemudian diambil sumpahnya. Saat awal dibentuknya banyak tantangan dihadapi DPD yaitu mulai dari kewenangan nya yang kurang memadai sebagai kamar kedua yang efektif dalam parlemen. Munculnya tantangan itu dikarena tidak banyak dukungan politik yang diberikan kelembaga ini.

kewenangan DPD yaitu dalam pasal 249 ayat 1 huruf $j$ yang berbunyi " DPDbertugas dan berwenang melakukan pemantauan dan evaluasi rancangan peraturan daerah dan peraturan daerah. Kewenangan baru ini menjadi kontroversi yaitu Pertama, Dalam Pasal 22D ayat (3) UUD 1945 objek pengawasan yang dilakukan oleh DPD terbatas yaitu pelaksanaan UU terkait dengan daerah maka dapat dimaknai sejauh mana UU itu diterapkan sehingga fungsi pengawasan yang dilakukan oleh DPD tidak dapat menyentuh materi peraturan pelaksana oleh karena itu kewenangan baru DPD yang berwenang melakukan pengawasan Perda bertentangan dengan konstitusi.

Kedua, Ada dua jalur pengujian peraturan perundang-undangan yang diberikan oleh UUD 1945. Pertama, pengujian (Judicial Review) UU terhadap UUD oleh Mahkamah Konstitusi. Kedua, Pengujian peraturan perundang-undangan dibawah UU terhadap UU oleh Mahkamah Agung.

1 Yusri Munaf, Konstitusi dan Kelembagaan Negara, Marpoyan Tujuh, Pekanbaru, 2014. HIm 7 
Berdasarkan Pasal 7 ayat (1) UU 12/2011, Perda termasuk dalam Peraturan Perundang-Undangan di bawah UU, sehingga hanya dapat diuji di MA. Pengawasan perda oleh DPD akan menimbulkan tumpang tindih wewenang antara kamar kedua parlemen dan MA. Ketiga, Kewenangan DPD dalam pengawasan preventif dapat menimbulkan tumpang tindih dengan kewenangan Pemerintah pusat. Berdasarkan UU Pemerintahan Daerah, suatu rancangan perda yang telah disetujui bersama oleh Dewan Perwakilan Rakyat Daerah dan kepala daerah harus mendapatkan nomor register dari Menteri Dalam Negeri (untuk perda provinsi) atau gubernur sebagai wakil pemerintah pusat (untuk perda kabupaten/kota) sebelum diundangkan dalam lembaran daerah. ${ }^{2}$

\section{Rumusan Masalah}

1. Bagaimana sistem perwakilan negara Amerika Serikat, Republik Rakyat Cina Dan Inggris ?

2. Bagaimana Eksistensi Kewenangan Dewan Perwakilan Daerah Dalam Melakukan Pemantauan Dan Evaluasi Rancangan Peraturan Daerah Dan Peraturan Daerah Berdasarkan UndangUndang Nomor 2 Tahun 2018 Tentang MPR, DPR, DPD Dan DPRD?

B. Tinjauan Teori

1. Trias Politica

Menurut sejarah pembagiannya kekuasaan Negara itu bermula dari gagasan tentang pemisahan kekuasaan Negara kedalam berbagai organ agar tidak terpusat ditangan seorang (Raja absolut). Gagasan itu antara lain dikemukan oleh Jhon Locke.3 Menurut Jhon Locke agar pemerintah tidak sewenang-wenang harus ada pembedaan pemegang kekuasaankekuasaan dalam Negara kedalam tiga macam kekuasaan, yaitu: kekuasaan legislatif, kekuasaan eksekutif dan kekuasaan federatif, yang masing-masing terpisah-pisah satu sama lain. ${ }^{4}$

1. Kekuasaan Legislatif, ialah wewenang untuk membuat undang-undang;

2. Kekuasaan Eksekutif, ialah wewenang untuk mempertahankan dan melaksanakan undang-undang serta mengadili perkara.

3. Kekuasaan Federatif, ialah wewenang yang tidak termasuk dalam wewenang Legislatif dan Eksekutif. Misalnya hubungan dengan luar negeri, inggris waktu itu mempunyai banyak tanah jajahan.

${ }^{2}$ https://www.kompasiana.com/fathrahman/5af26029ab12ae5a556894e2/dpdmen gawasi-perda.

${ }_{3}^{3}$ Mahfud MD, Dasar \& Struktur Ketatanegaraan Indonesia, Cet 2, Rineka Cipta, Jakarta, 2001.HIm 73

${ }^{4}$ Susilo Suharto, Kekuasaan Presiden RI Dalam Berlakunya UUD 1945, Graha IImu, Yogyakarta, 2006. HIm 41 
Montesquieu adalah ahli pemikir besar yang pertama diantara ahliahli pemikir besar tentang Negara dan hukum dari Perancis. Nama lengkapnya adalah Charles Secondat, Baron De Labrede Et The Montesquieu. la adalah seorang sarjana hukum hidup pada tahun 16881755. la adalah seorang Autodidact, yaitu seorang yang dengan pemikiran dan tenaga nya sendiri telah memperoleh kemajuan terutama dalam ilmu pengetahuan. Jabatan yang pokok adalah sebagai Hakim Mahkamah di Bordeaux.

Setelah dia mendapatkan banyak pengalaman di beberapa Negara ia tidak ingin memberikan pengajarannya yang bersifat revolusioner, melainkan ingin mengadakan perubahan terhadap ketatanegaraan yang telah ada, terutama di Perancis yang mana Perancis pada waktu itu melaksanakan sistem pemerintahan Absolutisme, dimana kekuasaan negara semua dipusatkan kepada satu tangan yaitu pada Raja. Sebab ia melihat keadaan lain seperti di Inggris disana menurut pendapatnya kekuasaan dibagi atau tegasnya dipisahkan menjadi tiga dan masingmasing kekuasaan itu dilaksanakan oleh satu badan yang berdiri sendiri yaitu:

1. Kekuasaan perundang-undangan (Legislatif)

2. Kekuasaan melaksanakan pemerintahan (Eksekutif)

3. Kekuasaan Kehakiman (Judikatif).

Teori pemisahan kekuasaan, yang disebut sebagai doktrin "Trias Politica" oleh Immanuel Kant. ${ }^{5}$ Dengan ajarannya itu Montesquieu berpendapat bahwa apabila kekuasaan Negara itu dipisahkan secara tegas menjadi tiga yaitu: kekuasaan perundang-undangan, kekuasaan melaksanakan pemerintah dan kekuasaan kehakiman dan masing-masing kekuasaan itu dipegang oleh badan yang berdiri sendiri ini akan menghilangnya kemungkinan timbulnya tindakan sewenang-wenang dari seorang penguasa atau tegasnya tidak memberikan kemungkinan dilaksanakan sistem pemerintahan Absolutisme. Inti ajaran Trias Politica ialah adanya pemisahan kekuasaan dalam Negara, sehingga dalam penyelenggaraan pemerintahan Negara tidak berada dalam kekuasaan satu tangan. ${ }^{6}$

Istilah pemisahan kekuasaan dalam pengalaman ketatanegaraan Indonesia itu cenderung di konotasikan dengan pendapat Montesquieu secara absolut. Konsep pemisahan kekuasaan itu dibedakan secara diametral dari konsep pembagian kekuasaan yang dikaitkan dengan sistem supremasi MPR yang secara mutlak menolak ide

5 Abdul Ghoffar, Perbandingan Kekuasaan Presiden Indonesia Setelah Perubahan UUD 1945 Dengan Delapan Negara Maju, Prenada Media Group, Jakarta, 2009. HIm 11

${ }^{6}$ Ellydar Chaidir, Sistem Pemerintahan Negara Republik Indonesia, Total Media, Yogyakarta, 2008. HIm 55 
pemisahan kekuasaan ala Trias Politica Montesqueiu. Dalam sidangsidang Badan Penyelidik Usaha Persiapan Kemerdekaan Indonesia pada tahun 1945, Soepomo misalnya menegaskan bahwa UUD 1945 tidak menganut doktrin Trias Politica dalam arti paham pemisahan kekuasaan ala Montesquieu melainkan menganut sistem pembagian kekuasaan.

Namun demikian, sekarang setelah UUD 1945 mengalami empat kali perubahan, dapat dikatakan bahwa sistem demokrasi konstitusi kita telah mengatur doktrin pemisahan kekuasaan itu secara nyata. Beberapa bukti mengenai hal ini antara lain adalah:

1. Adanya pergeseran kekuasaan Legislatif dari tangan Presiden ke DPR. bandingkan saja antara ketentuan pasal 5 ayat (1) UUD 1945 sebelum amandemen dengan pasal 5 ayat (1) dan pasal 20 ayat (1) UUD 1945 setelah perubahan dan pasal 20 ayat (1) UUD 1945 setelah perubahan. kekuasaan untuk membentuk undang-undang yang sebelumnya berada di tangan Presiden, sekarang beralih ke DPR.

2. Diadopsinya sistem pengujian konstitusional atas undangundang sebagai produk Legislatif oleh Mahkamah Konstitusi. Sebelumnya tidak dikenal adanya mekanisme semacam itu, karena pada pokoknya undang-undang tidak dapat diganggu gugat dimana hakim dianggap hanya dapat menerapkan undang-undang dan tidak boleh menilai undang-undang.

3. Diakuinya bahwa lembaga pelaku kedaulatan rakyat itu tidak hanya terbatas pada MPR, melainkan semua lembaga Negara baik secara langsung atau tidak langsung merupakan penjelmaan kedaulatan rakyat. Presiden, anggota DPR dan DPD sama-sama dipilih secara langsung oleh rakyat dan karena itu sama-sama merupakan pelaksana langsung prinsip kedaulatan rakyat.

4. Dengan demikian, MPR juga tidak lagi berstatus sebagai lembaga tertinggi Negara, melainkan merupakan lembaga (tinggi) Negara yang sama derajatnya dengan lembagalembaga (tinggi) Negara lainnya, seperti presiden, DPR, DPD, MK dan MA.

5. Hubungan antar lembaga Negara itu bersifat saling mengendalikan satu sama lain sesuai dengan prinsip checks and balance.

Dari kelima ciri tersebut di atas, dapat diketahui bahwa UUD 1945 tidak lagi menganut prinsip pembagian kekuasaan yang bersifat vertikal, tetapi juga tidak menganut paham Trias Politica Montesquieu yang memisahkan cabang-cabang kekuasaan Legislatif, Eksekutif Dan Yudikatif secara mutlak dan tanpa diiringi oleh hubungan saling mengendalikan satu sama lain. Dengan perkataan lain sistem baru yang dianut oleh UUD 
1945 pasca perubahan ke empat adalah sistem pemisahan kekuassan berdasarkan prinsip checks and balance.

\section{Teori Kewenangan}

Kewenangan (Authority, Gezag) adalah kekuasaan formal kekuasaan yang berasal dari kekuasaan legislatif (diberi oleh undangundang) ataupun dari kekuasaan eksekutif administratif. ${ }^{7}$ Secara yuridis wewenang adalah kemampuan dalam melakukan hubungan hukum yang diberikan oleh UU atau untuk bertindak dalam hukum publik. Wewenang pemerintahan itu sifatnya berbeda-beda ada yang bersifat Expressimplied, Fakultatif Dan Vrij Bestuur. wewenang yang bersifat Expressimplied memiliki isi yang bersifat umum dan individual kongret adapun wewenang ini merupakan wewenang yang memiliki maksud dan kejelasan tujuan serta patuh pada hukum yang tertulis dan yang tidak tertulis adapun isi dari wewenang ini. Misalnya membuat suatu peraturan, sedangkan yang isinya kongkret misalnya dalam bentuk rencana atau suatu keputusan seperti memberikan nasehat serta membuat Rencana Tata Ruang. ${ }^{8}$

Kelompok norma hukum yang terakhir adalah peraturan pelaksana (Verordung) dan peraturan otonom (Autonome Satzung). Peraturan pelaksanaan dan peraturan otonom ini merupakan peraturan-peraturan yang terletak dibawah undang-undang yang berfungsi menyelenggarakan ketentuan-ketentuan dalam undang-undang. Peraturan pelaksanaan bersumber dari kewenangan delegasi sedangkan peraturan otonom bersumber dari kewenangan atribusi. ${ }^{9}$

Atribusi kewenangan dalam pembentukan peraturan perundangundangan ialah pemberian kewenangan membentuk peraturan perundang-undangan yang diberikan oleh Undang-Undang Dasar atau Undang-undang kepada suatu lembaga Negara/Pemerintahan. Kewenangan tersebut melekat terus menerus dan dapat dilaksanakan atas prakarsa sendiri setiap waktu diperlukan, sesuai dengan batas-batas yang diberikan Contohnya: Undang-Undang Dasar Tahun 1945 dalam pasal 22 ayat (1) memberikan kewenangan kepada presiden untuk membentuk peraturan pemerintah pengganti undang-undang jika terjadi "hal ihwal kegentingan yang memaksa".

Delegasi kewenangan dalam pembentukan peraturan perundangundangan ialah pelimpahan kewenangan membentuk peraturan perundang-undangan yang dilakukan oleh peraturan perundangundangan yang lebih tinggi kepada peraturan perundang-undangan yang lebih rendah, baik pelimpahan dinyatakan dengan tegas maupun tindakan.

${ }^{7}$ Prajudi Atmosudijo, Hukum Administrasi Negara, Cet 10, Ghalia Indonesia, Jakarta,1994. HIm 78

${ }^{8} \mathrm{SF}$ Marbun, Peradilan Administrasi Dan Upaya Administratif Di Indonesia,Liberty, Yogyakarta, 2003. HIm 123

9 Mari Farida Indrati S, IImu Perundang-Undangan Jenis, Fungsi, Dan Materi Muatan, Cet 5, Kansisus, Yogyakarta, 2007. HIm 55 
Berlainan dengan kewenangan atribusi, pada kewenangan delegasi kewenangan tersebut tidak diberikan, melainkan diwakilkan dan selain itu kewenangan delegasi ini bersifat sementara dalam arti kewenangan ini dapat diselenggarakan sepanjang pelimpahan tersebut masih ada. Contohnya : Pasal 5 ayat (2) UUD 1945 yang merumuskan Presiden menetapkan peraturan pemerintah untuk menjalankan undang-undang sebagaimana mestinya. ${ }^{10}$

\section{Teori Perwakilan}

Ada dua teori klasik tentang hakekat hubungan wakil dengan terwakili yang terkenal yaitu teori mandat dan teori kebebasan. ${ }^{11}$ Dalam teori mandat wakil dilihat sebagai penerima mandat untuk merealisasikan kekuasaan terwakili dalam proses kehidupan politik. Bagi terwakili teori ini menguntungkan karena wakil dapat di kontrol terus menerus. Perbedaan pandangan antara wakil dengan terwakili dapat mengakibatkan menurunnya reputasi wakil. Dalam teori kebebasan wakil dapat bertindak tanpa tergantung atau terikat secara ketat oleh terwakili menurut teori ini, si wakil adalah orang-orang terpercaya dan terpilih serta memiliki kesadaran hukum masyarakat yang diwakilinya sehingga wakil dapat bertindak atas nama mereka yang diwakilinya atau atas nama rakyat.

Dalam rangka pelembagaan fungsi Representasi itu, dikenal pula adanya tiga sistem perwakilan yang dipraktikkan di berbagai Negara Demokrasi. Ketiga fungsi itu adalah: ${ }^{12}$

1. Sistem Perwakilan Politik (Political Representation)

2. Sistem Perwakilan Teritorial (Territorial Atau Regional Representation)

3. Sistem Perwakilan Fungsional (Functional Representation)

Sistem perwakilan politik menghasilkan wakil-wakil politik, sistem perwakilan teritorial menghasilkan wakil-wakil daerah. Sementara sistem perwakilan fungsional menghasilkan wakil-wakil golongan fungsional. Misalnya anggota DPR yang berasal dari partai politik merupakan contoh dari perwakilan politik, sementara anggota DPD yang berasal dari tiap-tiap Daerah Provinsi dalah contoh dari perwakilan teritorial sedangkan utusan golongan dalam sistem keanggotaan MPR di masa orde baru (sebelum perubahan UUD 1945) adalah contoh dari sistem perwakilan fungsional.

Dianutnya ketiga sistem perwakilan politik, perwakilan teritorial dan perwakilan fungsional menentukan bentuk dan struktur pelembagaan sistem perwakilan itu disetiap Negara. Pilihan sistem itu selalu tercermin dalam struktur kelembagaan parlemen yang dianut suatu Negara. Pada umumnya, di setiap Negara dianut salah satu atau paling banyak dua dari

${ }^{10}$ Ibid, HIm 56

${ }^{11}$ Abdy Yuhana, Sistem Ketatanegaran Indonesia Pasca Amandemen UUD 1945 Sistem Perwakilan Di Indonesia Dan Masa Depan MPR, Fokus Media, Bandung, 2013. HIm 54

12 Ibid, HIm 305 
tiga sistem tersebut secara bersamaan. Dalam hal negara yang bersangkutan menganut salah satu dari ketiganya pelembagaan tercermin dalam struktur parlemen satu kamar. Artinya struktur lembaga perwakilan rakyat yang dipraktikkan oleh Negara itu mestilah parlemen satu kamar (unicameral parliament). Jika yang dianut mencakup dua fungsi kedua fungsi itu selalu dilembagakan dalam struktur parlemen dua kamar.

Dalam sistem ketatanegaraan Indonesia bentuk lembaga perwakilan mengarah/mengidinkasi kepada bentuk sistem Tricameralisme. Justru yang menarik adalah bahwa Majelis Permusyawaratan Rakyat Republik Indonesia berdasarkan UUD 1945 sebelum amandemen menggabungkan ketiga sistem perwakilan tersebut diatas sekaligus. Pasal 2 ayat (1) UUD 1945 sebelum perubahan menentukan: "MPR terdiri atas anggota-anggota DPR ditambah dengan utusan-utusan dari daerah dan golongan-golongan menurut aturan yang ditetapkan dengan undangundang".

Didalamnya terdapat tiga unsur anggota, yaitu : anggota DPR sebagai perwakilan politik, utusan daerah dari daerah provinsi dan utusan golongan berasal dari golongan fungsional. Sekarang setelah perubahan keempat UUD 1945 Pasal 2 ayat (1) berbunyi : "MPR terdiri atas anggota DPR dan anggota DPD yang dipilih melalui pemilihan umum dan diatur lebih lanjut dengan undang-undang". Dengan demikian unsur utusan golongan fungsional dihilangkan sama sekali dari keanggotaan MPR pasca reformasi. Lembaga MPR dapat dikatakan merupakan institusi ketiga dalam struktur parlemen Indonesia, Sehingga Menurut Jimly Asshiddiqie sistem parlemen tiga kamar atau dikenal (tricameralisme). Namun demikian, meskipun MPR itu adalah kamar ketiga, sifat dan pekerjaan MPR itu sendiri bersifat ad hoc. Sebagai organ negara, lembaga MPR itu baru dapat dikatakan ada, apabila fungsinya sedang bekerja (in action). Namun, kalau melihat hasil pembahasan dari PAH I BP MPR akhirnya menyepakati rumusan sebagaimana tercantul dalam Pasal 22D yang secara jelas menunjukkan konstitusi Indonesia menganut bicameral yang lembut atau lunak (soft bicameralisme) dimana satu lembaga perwakilan mempunyai kekuatan lebih kuat (DPR) dibanding lembaga perwakilan lainnya (DPD).

\section{Metode Penelitian}

1. Jenis dan Sifat Penelitian

Jenis penelitian ini termasuk dalam golongan penelitian hukum normatif adalah penelitian kepustakaan, yaitu penelitian terhadap data sekunder. ${ }^{13}$ Sedangkan dilihat dari sifatnya adalah deskriptif analitis yaitu analisis yang dilakukan untuk menilai karakteristik dari sebuah data.

2. Obyek Penelitian

${ }^{13}$ Zainuddin Ali, Metode Penelitian Hukum, Sinar Grafika, Jakarta, 2014. HIm 
Obyek penelitian ini mengenai Kewenangan Dewan Perwakilan Daerah (DPD) Dalam Melakukan Pemantauan Dan Evaluasi Rancangan Peraturan Daerah (Ranperda) Dan Peraturan Daerah (Perda) Berdasarkan Undang-Undang Nomor 2 Tahun 2018.

3. Data dan Sumber Data

Dalam penelitian hukum normatif data dan sumber data yang digunakan adalah data sekunder yang dapat dikelompokkan menjadi:

a. Bahan hukum primer merupakan bahan yang menjadi sumber utama dalam penelitian. Bahan hukum primer dalam penelitian ini adalah : Undang-Undang Dasar Negara Republik Indonesia Tahun 1945, Undang-undang Nomor 2 Tahun 2018 Tentang Majelis Permusyawaratan Rakyat, Dewan Perwakilan Rakyat, Dewan Perwakilan Daerah, Dewan Perwakilan Rakyat Daerah (MD3), Undang-Undang Nomor 12 Tahun 2011 Tentang Pembentukan Peraturan Perundang-undangan, Undang-Undang Nomor 23 Tahun 2014 Tentang Pemerintahan Daerah, Undang-undang Nomor 7 Tahun 2017 tentang Pemilihan Umum, Putusan Mahkamah Konstitusi Nomor 56/PUU-XIV/2016 Tentang Pengujian Pasal 251 Ayat (5),(7) Undang-Undang Nomor 23 Tahun 2014 Tentang Pemerintahan Daerah Tentang Pembatalan Peraturan Daerah Provinsi, Putusan Mahkamah Konstitusi Nomor 137/PUU-XIII/2015 Tentang Pengujian Pasal 251 Undang-Undang Nomor 23 Tahun 2014 Tentang Pemerintahan Daerah Tentang Pembatalan Perda Kabupaten/kota. Putusan Mahkamah konstitusi (MK) Nomor 92/PUU-X/2012 Tentang Pengujian Undan-undang Nomor 12 Tahun 2011 Tentang Pembentukan Peraturan Perundangundangan Dan Undang-undang Nomor 17 Tahun 2014 Tentang MPR,DPR,DPD Dan DPRD (MD3) Tentang Kedudukan DPD, Peraturan Menteri Dalam Negeri Nomor 80 Tahun 2015 Tentang Pembentukan Produk Hukum Daerah.

b. Bahan hukum sekunder yang terutama adalah buku-buku hukum termasuk skripsi, tesis dan disertasi. Disamping itu juga jurnal hukum atau majalah ilmiah yang diterbitkan oleh lembaga pendidikan. $^{14}$

c. Bahan hukum tersier merupakan bahan-bahan yang mempunyai fungsi untuk memberikan penjelasan terhadap bahan hukum primer dan bahan hukum sekunder. Bahan hukum tersier antara lain kamus hukum/bahasa, ensiklopedi, dan lain-lain.

4. Anlisis Data dan Metode Penarikan Kesimpulan

Peneliti bidang hukum dengan menggunakan metode penelitian hukum normatif, dan data dianalisis secara kualitatif. Analisis secara kualitatif merupakan analisis dengan cara

\footnotetext{
${ }^{14}$ Suratman, Metode Penelitian Hukum, Alfabeta, Bandung, 2014. HIm77
} 
mendeskripsikan/menggambarkan, kemudian membandingkan antara data dengan ketentuan-ketentuan peraturan perundang-undangan atau pendapat para ahli hukum. Penarikan kesimpulan dilakukan dengan cara induktif penyimpulan dari hal-hal yang bersifat khusus kepada hal-hal yang bersifat umum.

\section{Hasil penelitian dan pembahasan}

A. Sistem perwakilan di beberapa negara

\section{Amerika Serikat}

Amerika merupakan negara federal, menganut sistem perwakilan bicameral yang disebut congress. Anggota congress terdiri dari House of Representative dan senate. Keanggotaan senate dipilih melalui pemilihan umum dengan masa jabatan enam tahun. Wewenangnya jauh lebih besar dari house of representative. Menurut penelitian Arend Lijphart, Amerika serikat dikategorikan sebagai Strong bicameralism, karena mempunyai symmetrical chambers dengan kekuasaan yang diberikan konstitusi sama dengan kamar pertama, dan juga mempunyai legitimasi demokratis karena dipilih secara langsung, dan juga incongruent komposisinya (Article 1 section 3, konstitusi amerika serikat) House of representative sebagai perwakilan politik, sedangkan senat sebagai perwakilan negara bagian. ${ }^{15}$. Konstitusi memberi kekuasaan khusus kepada Amerika serikat, yaitu sebagai berikut:

1. Senat merupakan kekuasaan satu-satunya untuk mencoba semua impeachment. Ketika dalam keadaan ini, mereka harus disumpah atau dengan penguatan/afirmasi. Ketika Presiden Amerika Serikat diadili, yang mengetuai pengadilan tersebut adalah ketua mahkamah agung dan tidak seorang pun yang dapat dihukum tanpa persetujuan dua pertiga dari anggota yang hadir (Article I, Section 3, Par 6)

2. Keputusan dalam kasus impeachment harus tidak memperpanjang lebih jauh dengan pemecatan dari jabatan, dan diskualifikasi untuk menangani dan menikmati jabatan, kepercayaan atau keuntungan di bawah amerika serikat, tetapi hukuman partai merupakan suatu keharusan, meskipun begitu dapat dikenakan dan tunduk pada dakwaan, pengadilan keputusan dan hukuman menurut hukum (Article, Section 3, Par 7).

3. Senat harus memberi persetujuan (dengan suara setuju dua pertiga dari seluruh suara) kepada setiap perjanjian yang diadakan oleh amerika serikat, sebelum perjanjian itu dapat berlaku.

${ }^{15}$ Hartati, Menatap Masa Depan Dewan Perwakilan Daerah, CV Trisar Mitra Utama, Jambi, 2018, HIm 121 
4. Senat mempunyai hak untuk menyetujui atau tidak terhadap pengangkatan-pengangkatan duta-duta besar, para menteri kabinet dan konsul, hakim Mahkamah Agung dan lain-lain pegawai USA yang masih akan ditetapkan dengan undangundang.

Menurut konstitusi Amerika Serikat, kongres adalah badan legislatif, yaitu badan yang membentuk undang-undang. Kekuasaan dimaksud, tercantum dalam Pasal 1 ayat (1) sebagai berikut: "All legislative power here in granted shall be vested in a Senate and House Of Representatives" (seluruh kekuasaan perundang-undangan yang ada berdasarkan konstitusi ini diletakkan pada sekual kongres yang terdiri dari senat dan DPR)". Konstitusi meletakkan kekuasaan untuk memberlakukan undang-undang pada kongres. Sebuah usulan yang dipertimbangkan oleh kongres disebut rancangan undang-undang. Jika sebagian besar dari masing-masing kamar di kongres dua pertiga anadaikata Presiden memvetonya sepakat untuk menerima sebuah rancangan undangundang, maka ia menjadi undang-undang.

2. Republik Rakyat Cina

RRC adalah sebuah negara demokrasi yang menganut asas sentralisme, dan pelaksanaan kedaulatan rakyat adalah lembaga tertinggi negara. Untuk menjalankan peranannya sehari-hari oleh Kongres Rakyat Nasional dibentuk suatu Komite Tetap atau The Standing Committtee. Kongres Rakyat Nasional terdiri dari wakil-wakil rakyat yang dipilih oleh provinsi-provinsi, Daerah Otonom, Kotamadya yang langsung tunduk pada pemerintahan pusat dan angkatan bersenjata. Pemilihan umum ini dipimpin oleh Komite Tetap Kongres Rakyat Nasional. Peranan Kongres Rakyat Nasional dalam bentuk tugas dan kewenangan antara lain: ${ }^{16}$

a. Mengubah UUD/Konstitusi

b. Mengawasi pelaksanaan Konstitusi

c. Menyusun dan merevisi atau meninjau kembali undang-undang pokok tentang kejahatan, perdata sipil, susunan kenegaraan dan lain-lain;

d. memilih presiden dan wakil presiden;

e. memutuskan pemilihan perdana menteri atas calon yang diajukan oleh presiden RRC, memutuskan pemilihan wakil perdana menteri, dewan negara, menteri-menteri, pimpinan dalam lembaga, kepala pemeriksaan keuangan negara, sekretaris jenderal dewan negara, atas pencalonan perdana menteri;

f. memilih pimpinan dari angkatan perang pusat atas pencalonannya untuk anggota angkatan perang pusat;

g. memilih ketua mahkamah agung;

${ }^{16}$ Abdy Yuhana, Sistem Ketatanegaran Indonesia Pasca Amandemen UUD 1945 Sistem Perwakilan ...,Op.Cit, HIm 107, 
h. memilih ketua kejaksaan agung;

i. menilai dan menyetujui anggaran belanja negara dan laporan pelaksanaannya;

j. menilai dan menyetujui rencana-rencana pembangunan bidang ekonomi dan sosial dan laporan pelaksanannya;

k. mengubah atau mencocokkan keputusan-keputusan dari komite tetap kongres rakyat nasional;

1. menyetujui pembentukan provinsi-provinsi, daerah otonom dan kota madya yang langsung di bawah pemerintah pusat;

m. menentukan pembentukan daerah administrasi khusus dan menentukan peraturannya (sistem) yang diterapkan;

n. menyatakan keadaan perang dan damai; dan

o. menjalankan tugas dan wewenang lainnya yang dianggap perlu oleh lembaga tertinggi negara.

Disamping itu kongres Rakyat Nasional Cina mempunyai kekuasaan untuk mengganti/merecall dari jabatannya: ${ }^{17}$

a. Presiden dan Wakil Presiden RRC;

b. Perdana Menteri dan wakil perdana menteri; para anggota dewan negara, menteri-menteri, pimpinan lembaga-lembaga negara (departemen), kepala pemeriksaan keuangan sekretaris jenderal dewan negara;

c. pimpinan angkatan perang dan pejabat militer di bawahnya;

d. Ketua Mahkamah Agung;

e. Ketua Kejaksaan Agung;

Dari ketentuan tersebut diatas, tampak kedudukan kongres Rakyat Nasional benar-benar sebagai Lembaga Tertinggi negara dan pelaksanaan kedaulatan rakyat, di mana semua lembaga atau badan negara tunduk dan bertanggungjawab kepadanya. Peranan sebagai lembaga tertinggi negara begitu luas dan tidak insidensial (temporer). Di samping peranan (tugas dan kewenangan) tersebut di atas, melalui komite tetap (the standing comittee) kongres rakyat nasional menjalankan fungsi sebagai berikut:

a. Menafsirkan konstitusi dan mengawasi pelaksanaannya;

b. menyusun dan mengubah undang-undang dengan pengecualian bahwa akan disetujui oleh kongres rakyat nasional kemudian;

c. Mengumumkan bagian tambahan dan perubahan atas undangundang telah disetujui oleh kongres rakyat nasional pada saat tidak bersidang;

d. Menafsirkan undang-undang;

17 Ibid, HIm 109 
e. Menilai dan memberi persetujuan suatu bagian yang sesuai yang dianggap penting dari rencana pembangunan ekonomi dan sosial serta anggaran bagi pelaksanaannya;

f. Membatalkan tindakan dan peraturan pemerintah, keputusan atau perintah yang bertentangan dengan konstitusi dan undangundang;

g. Membatalkan peraturan daerah atau keputusan pemerintah daerah, daerah otonom atau kotamadya yang langsung di bawah pemerintah pusat yang bertentangan dengan konstitusi, undang-undang atau peraturan pemerintah;

h. Menentukan pada saat kongres rakyat nasional tidak bersidang atas keputusan (penentuan) dari menteri-menteri, ketua komisi, ketua pemeriksaan keuangan dan sekretaris jenderal berdasarkan usulan perdana menteri;

i. Memutuskan pada saat kongres rakyat nasional tidak bersidang penunjukan staf (anggota) dari angkatan bersenjata (perang) atas usulan penglima;

j. Menentukan dan mengganti wakil ketua dan anggota (hakim) pada mahkamah agung ketua mahkamah militer atas usulan ketua mahkamah agung;

k. Menentukan dan mengganti wakil ketua kejaksaan agung, jaksa agung pada kejaksaan agung dan ketua kejaksaan militer atas rekomendasi dan ketua kejaksaan agung dan menyetujui penunjukan dan penggantian dari kepala kejaksaan provinsi, daerah otonom atau kotamadya yang langsung di bawah pemerintah pusat; dan

1. Tugas-tugas lain yang disebutkan dalam Pasal 67 konstitusi 1982 RRC.

Sistem perwakilan dalam penerapan kedaulatan rakyat, tetapi juga sebagai lembaga tertinggi negara yang memiliki kekuasaan penuh menentukan kehidupan ketatanegaraan cina. peranannya yang cukup luas dan menentukan diwujudkan dalam sistem penentuan atu penerapan organ-organ dan pejabat-pejabat negara yang tunduk dan bertanggungjawab kepada kongres rakyat nasional. Adannya komite tetap (The Standing Comitte) menjamin peranan kongres rakyat nasional tidak bersifat temporer dan efektif. ${ }^{18}$

3. Inggris

Inggris telah banyak memberikan sumbangan kepada peradaban dunia, dan yang paling besar, barangkali, sumbangannnya terhadap lembaga-lembaga demokrasi. Inggris dikenal dan dijuluki sebagai "induk parlementaria" (Mother Of Parliaments) karena di dunia barat setelah

${ }^{18}$ Ellydar Chaidir, Sistem Pemerintahan Negara Republik Indonesia.., Op.Cit, HIm 
runtuhnya kerajaan romawi, inggrislah yang pertama kali menciptakan suatu parlemen yang workable, yaitu sebuah dewan perwakilan yang dipilih oleh rakyat dengan kekuasaan untuk memecahkan problemproblem sosial dan ekonomi melalui perdebatan yang bebas dan mengarah pada pembuatan undang-undang. Dengan demikian, inggris telah berhasil mengganti civil war dengan civil code. ${ }^{19}$

Untuk kekuasaan legislatif, walaupun merupakan sebuah negara yang berbentuk monarkhi, namun dalam kehidupan demokrasi di inggris dikenal adanya parlemen dua kamar yang terdiri dari House Of Commons dan House Of Lords. Sebagai majelis rendah (lower chamber), House Of Commons berisikan anggota yang dipilih melalui pemilihan umum dan memiliki wewenang legislasi dan kontrol terhadap pemerintah, yang cenderung lebih luas daripada House Of Lords. House Of Commons merupakan kamar di parlemen yang mencerminkan perwakilan bangsa, yaitu jumlah penduduk yang tinggal dalam terirori Inggris, sedangkan House of Lords terdiri dari anggota yang tidak dipilih melalui pemilu dan juga tidak menerima kompensasi finansial dari jabatannya. Selain terdiri dari keturunan golongan bangsawan (Hereditary peers), keanggotaan house of lords juga berisikan para pangeran kerajaan, para pemuka gereja, perwakilan masyarakat Irlandia dan Skotlandia, serta 12 orang hakim dan praktisi hukum terkemuka lainnya yang melaksanakan fungsi yudisial dari House of Lords. Majelis tinggi ini memang sekaligus berperan sebagai mahkamah tingkat akhir bagi seluruh perkara pidana atau perdata yang diajukan ke peradilan inggris Sebuah Mahkamah Agung yang disebut Law Lords.

Kekuasaan House of Commons dan House of Lords dibatasi oleh beberapa ketentuan undang-undang (acts) dan konvensi ketatanegaraan (convention). Seperti misalnya, the parliament acts 1911 dan 1949 yang menentukan kekuasaan kamar-kamar tersebut bagi perumusan suatu rancangan undang-undang (bills). Dalam parliament acts diatur mengenai hubungan antara masing-masing kamar di parlemen inggris ketika menjalankan kekuasaan legislasinya. Misalnya, ditentukan suatu rancangan undang-undang yang memuat masalah keuangan harus berasal dari commons dan sudah mendapatkan persetujuan dari kerajaan (Royal Assent) paling lama satu bulan setelah rancangan undang-undang tersebut diajukan ke Lords, meskipun tidak mendapat persetujuan dari Lords. Dengan adanya kekuasaan seperti ini, tampaklah bahwa parlemen mempunyai peran yang sangat aktif dalam menjalankan pemerintah. 
B. Eksistensi Kewenangan DPD Dalam Melakukan Pemantauan Dan Evaluasi Rancangan Peraturan Daerah Dan Peraturan Daerah

1. Fungsi legislasi DPD

Fungsi legislasi diistilahkan juga dengan fungsi pembuatan undangundang atau fungsi perumusan undang-undang. Terhadap fungsi legislasi ini, B.N. Marbun, berpandangan bahwa pada hakikatnya, dilihat dari sudut materiil, membuat undang-undang adalah tindakan memutuskan untuk membuat undang-undang adalah tindakan memutuskan untuk membuat peraturan umum. Dilihat dari sudut formal, pembuatan suatu undangundang berarti suatu keputusan untuk membuat undang-undang yang dilakukan oleh satu badan (lembaga), atau beberapa badan yang berwenang dan bekerjasama sesuai dengan ketentuan hukum yang berlaku disuatu negara. ${ }^{20}$

Apabila pandangan diatas dijadikan sebagai landasan teoritik dalam memutuskan apakah yang dimaksud atau dikategorikan dengan fungsi legislasi, maka syarat utama atas kegiatan tersebut adalah terdapat suatu tindakan untuk memutuskan atau memberikan keputusan untuk membuat undang-undang. Oleh karenanya berdasarkan pandangan diatas, apakah kewenangan yang dimiliki oleh DPD sebagaimana yang diatur menurut Pasal 22 D ayat (1) dan (2) UUD NRI 1945 dapat dikategorikan sebagai bentuk legislasi yang dimiliki oleh DPD? Bukankah kewenangan yang dimiliki oleh DPD sebagaimana yang diatur menurut ketentuan pasal tersebut hanya merupakan kewenangan untuk mengajukan rancangan undang-undang dan memberikan pertimbangan kepada DPD atas rancangan undang-undang. Kewenangan-kewenangan tersebut jelas bukan merupakan atau tidak termasuk dalam kategori untuk memutuskan atau meberikan keputusan atas rancangan undang-undang sebagaimana pengertian legislasi yang dikemukakan di atas. ${ }^{21}$

Pandangan ahli lainnya misalnya dikemukakan oleh Jimly Asshidiqie. Menurutnya fungsi legislasi adalah mencakup kegiatan mengkaji, merancang, membahas dan mengesahkan undang-undang. Pandangan tersebut secara jelas membedakan bahwa lingkup fungsi legislasi tidak hanya terbatas pada kegiatan untuk memberikan keputusan atas peraturan perundang-undangan tetapi juga terhadap kegiatan pengkajian, merancang, membahas dan mengesahkan adalah merupakan lingkup dari legislasi itu. Oleh karena itu, kewenangan yang melekat pada DPD yang meliputi kewenangan untuk mengajukan usulan rancangan undang-undang, ikut membahas dan memberikan pertimbangan atas rancangan undang-undang belum memenuhi lingkup fungsi legislasi secara utuh dengan kata lain dapat dinyatakan belum memenuhi fungsi legislasi yang sesungguhnya, karena kewenangan yang dimiliki oleh DPD

${ }^{20}$ Hartati, Menatap Masa Depan Dewan Perwakilan Daerah.., Op.Cit,2018. HIm

21 Ibid, HIm 237-238 
tersebut tidak sampai pada kewenangan untuk ikut mengesahkan rancangan undang-undang untuk kemudian menjadi undang-undang. ${ }^{22}$

DPD "hanya" mempunyai kewenangan dapat mengajukan rancangan undang-undang tertentu ke DPR sebagaimana tercantum dalam Pasal 22D ayat (1). Selanjutnya DPR lah yang menentukan "nasib" rancangan undang-undang tersebut, apakah akan dibahas lebih lanjut oleh DPR ataukah perjalanannya hanya cukup sampai pada penyerahan konsep tersebut dari DPD ke DPR. Kewenangan DPD "ikut membahas rancangan undang-undang berkaitan dengan otonomi daerah, hubungan pusat dan daerah, pembentukan, pemekaran dan penggabungan daerah, pengelolaan sumber daya alam dan sumber daya ekonomi serta perimbangan keuangan pusat dan daerah" dan memberikan pertimbangan atas rancangan undang-undang tersebut" kepada DPR. Akan tetapi, DPD mutlak diikut sertakan dalam membahas rancangan undang-undang itu. Sebelumnya DPD ikut membahas RUU pada tingkat I yaitu dalam rapat komisi, rapat gabungan komisi, rapat Badan Legislasi, Rapat Badan Anggaran atau Rapat Panitia Khusus. Mahkamah konstitusi dalam sidang pleno pada 27 maret 2013 mengabulakn permohonan DPD untuk sebagian. Putusan Mahkamah konstitusi 92/PUU-X/2012 yang amar putusannya menyebutkan bahwa kedudukan DPD di bidang legislasi setara DPR dan Presiden. DPD berhak dan/atau berwenang mengusulkan rancangan undang-undang tertentu dan membahas rancangan undangundang tertentu sejak awal hingga akhir tahapan, namun DPD tidak memberi persetujuan atau pengesahan rancangan undang-undang menjadi undang-undang. Mahkamah Konstitusi juga memutuskan DPR, DPD dan pemerintah menyusun program legislasi nasional. ${ }^{23}$

Dengan demikian, jelaslah bahwa fungsi DPD dalam legislasi itu hanyalah sebagai co-legislator disamping DPR. Sifat tugasnya hanya menunjang (Auxialiary Agency) terhadap tugas-tugas konstitusional DPR. Dalam proses pembentukan suatu Undang-undang atau legislasi, DPD tidak mempunyai kekuasaan untuk memutuskan atau berperan dalam proses pengambilan keputusan sama sekali. Padahal, persyaratan dukungan menjadi anggota DPD jauh lebih berat dibandingkan dengan persyaratan dukungan menjadi anggota DPR. Artinya, kualitas legitimasi anggota DPD itu sama sekali tidak diimbangi secara sepadan oleh kualitas kewenangannya sebagai wakil Rakyat Daerah (Regional Representatives). ${ }^{24}$

Syarat untuk menjadi anggota DPD lebih berat dibanding menjadi anggota DPR sebagaimana dalam "Undang-undang Nomor 7 Tahun 2017

${ }^{22} \mathrm{Ibid}, \mathrm{HIm}$ 238- 239

${ }^{23}$ Patrialis Akbar, Lembaga-Lembaga Negara Menurut UUD NRI Tahun 1945, Cet 2, Sinar Grafika, Jakarta, 2015. HIm 80

24 Jimly Asshidiqie, Perkembangan \& Konsolidasi Lembaga Negara Pasca Reformasi, Cet 2, Sinar Grafika, Jakarta, 2012. HIm 121. 
Tentang Pemilihan Umum Pasal 183 Ayat (1) yang berbunyi: Provinsi dengan jumlah penduduk yang temuat didalam daftar pemilih tetap sampai dengan 1.000 .000 (satu juta) orang wajib mendapatkan dukungan paling sedikit 1.000 seribu) Pemilih; Provinsi dengan jumlah penduduk yang termuat didalam daftar pemilih tetap lebih dari 1.000 .000 (satu juta) sampai dengan 5.000.000 (lima juta) orang wajib mendapatkan dukungan paling sedikit 2.000 (dua ribu) Pemilih; Provinsi dengan jumlah penduudk yang termuat didalam daftar pemilih tetap lebih dari 5.000.000 (lima juta) sampai dengan 10.000 .000 (sepuluh juta) orang wajib mendapatkan dukungan paling sedikit 3.000 (tiga ribu) Pemilih; provinsi dengan jumlah penduduk yang termuat di dalam daftar Pemilih tetap lebih dari 10.000.000 (sepuluh juta) sampai dengan 15.000.000 (lima belas juta) orang wajib mendapatkan dukungan paling sedikit 4.000 (empat ribu) Pemilih; dan provinsi dengan jumlah penduduk yang termuat di dalam daftar Pemilih tetap lebih dari 15.000.000 (lima belas juta) orang harus mendapatkan dukungan paling sedikit 5.000 (lima ribu) Pemilih".

2. Fungsi Pengawasan

Rumusan kewenangan ini juga merupakan konsekuensi logis belaka dari kewenangan DPD yang terbatas sekaligus ketergantungan pelaksanaan hasil kerja DPD oleh lembaga diluar dirinya. Fungsi pengawasan DPD sebagaimana dirumuskan pada awal pasal ini sudah sangat baik dan tepat dikarenakan memang demikianlah salah satu fungsi DPD sebagai lembaga perwakilan. Dalam melakukan fungsi pengawasan kinerja pemerintahan DPD mempunyai kewenangan penuh. Oleh karena itu, dibidang pengawasan DPD dapat lebih berkonsentrasi, sehingga keberadaannya dapat dirasakan efektivitasnya oleh masyarakat di daerahdaerah. ${ }^{25}$ Namun rumusan yang baik tersebut menjadi berkurang nilainya karena hasil pengawasan tersebut tidak dapat dieksekusi sendiri oleh DPD, tetapi harus diserahkan kepada DPR.

Kedudukan hasil pengawasan yang dilakukan DPD dimata DPR adalah sebagai bahan pertimbangan bagi DPR untuk ditindaklanjuti kata "sebagai bahan pertimbangan" dan "untuk ditindaklanjuti" oleh DPR menunjukkan hasil kerja DPD tersebut hanya diposisikan sebagai bahan pertimbangan yang sudah tentu tidak ada keharusan bagi DPR untuk melaksanakannya atau menjadi bagian keputusan DPR. Namun dalam etika hubungan antar lembaga Negara, seyogyanya temua-temuan DPD ditindaklanjuti oleh DPR untuk disampaikan kepada lembaga-lembaga penegak hukum. Apabila DPR tidak menindaklanjuti temuan DPD tersebut maka tidak dilarang DPD secara langsung menyampaikan pendapat DPD kepada penegak hukum.

${ }^{25}$ Ibid, HIm 119 


\section{DPD berwenang melakukan pemantauan dan evaluasi rancangan peraturan daerah dan peraturan daerah}

Peraturan daerah merupakan salah satu sarana dalam penyelenggaraan otonomi Daerah. Kewenangan membuat Peraturan Daerah (perda), merupakan wujud nyata pelaksanaan hak otonomi yang dimiliki oleh suatu Daerah dan sebaliknya. ${ }^{26}$ Suatu Peraturan daerah berfungsi sebagai penjabaran lebih lanjut dari peraturan perundangundangan yang lebih tinggi dan tidak boleh bertentangan dengan peraturan perundang-undangan yang lebih tinggi, kepentingan umum, peraturan daerah lain. Perda yang bersifat mengatur diundangkan dengan menempatkannya dalam lembaran daerah dan dengan demikian mempunyai kekuatan hukum yang mengikat. ${ }^{27}$ Perda dibentuk melalui atribusi kewenangan yaitu pemberian kewenangan membentuk peraturan perundang-undangan yang diberikan oleh Undang-undang pemerintahan daerah. Perda merupakan peraturan perundang-undangan yang derajatnya dibawah undang-undang sebagaimana tertuang dapat Pasal 7 ayat (1) Undang-undang Nomor 12 Tahun2011 yaitu berbunyi: Jenis dan hierarki Peraturan Perundang-undangan terdiri atas:
a. UUD NRI Tan 1945
b. TAP MPR
c. UU/Perppu
d. $P P$
e. Perpres
f. Perda Provinsi
g. Perda Kabupaten/Kota

Dalam beberapa UU Pemerintahan Daerah yang pernah atau sedang berlaku di Indonesia diatur pula pengujian terhadap rancangan Peraturan Daerah (executive preview) dalam rangka pengawasan dan pembinaan penyelenggaraan otonomi daerah (pengawasan preventif). ${ }^{28}$ Pengawasan Preventif adalah pengawasan terhadap Perda dan keputusan kepala daerah ketika masih berbentuk rancangan setelah dilaksanakan pengawasan kemudian pengesahan barulah peraturan itu berlaku.

Tahapan pengawasan preventif yang lazim disebut atau diistilahkan mekanisme "Eksekutif Preview" Perda. Mekanisme "eksekutif preview" pada prinsipnya mempunyai 3 (tiga) standar normatif atau batu uji yang digunakan yakni : Pertama, apakah pembentukan dan pemberlakuan

26 J. Kaloh, Mencari Bentuk Otonomi Daerah Suatu Solusi Dalam Menjawab Kebutuhan Lokal Dan Tantangan, Cet 2, PT Rineka Cipta, Jakarta 2007. HIm 131

27 Husnu Abadi, Dari Plagiat Sampai Ke Contempt Of Court, UIR Press, Pekanbaru, 2005. HIm 2

${ }_{28}$ Machmud Aziz, Pengujian Peraturan Perundang-Undangan Dalam Sistem Perundang-Undangan Indonesia, Jurnal Konstitusi, Volume 7, Nomor 5 Oktober. HIm 142 
sebuah perda tersebut bertentangan dengan ketentuan peraturan perundang-undangan yang lebih tinggi ataukah tidak. Kedua, untuk memastikan keberlakuan Perda tersebut tidak kontras dengan kepentingan umum. Ketiga, implementasi Perda tersebut dapat dipastikan tidak melanggar nilai-nilai atau norma kesusilaan. ${ }^{29}$

Sebagaimana pengawasan preventif terkait evaluasi Rancangan Peraturan Daerah telah diatur oleh Undang-Undang Nomor 23 Tahun 2014 tentang Pemerintahan Daerah Pasal 245 yang berbunyi:

1. Rancangan Perda Provinsi yang mengatur tentang RPJPD, RPJMD, APBD, perubahan APBD, pertanggungjawaban pelaksanaan APBD, pajak daerah, retribusi daerah dan tata ruang daerah harus mendapatkan evaluasi Menteri sebelum ditetapkan oleh gubernur.

2. Menteri dalam melakukan evaluasi Rancangan Perda Provinsi tentang pajak daerah dan retribusi daerah sebagaimana dimaksud pada ayat (1) berkoordinasi dengan menteri yang menyelenggarakan urusan pemerintahan bidang keuangan dan untuk evaluasi Rancangan Perda Provinsi tentang tata ruang daerah berkoordinasi dengan menteri yang menyelenggarakan urusan pemerintahan bidang tata ruang.

3. Rancangan Perda kabupaten/kota yang mengatur tentang RPJPD, RPJMD, APBD, perubahan APBD, pertanggungjawaban pelaksanaan APBD, pajak daerah, retribusi daerah, dan tata ruang daerah harus mendapat evaluasi gubernur sebagai wakil Pemerintah Pusat sebelum ditetapkan oleh bupati/wali kota.

4. Gubernur sebagai wakil Pemerintah Pusat dalam melakukan evaluasi rancangan Perda Kabupaten/Kota tentang pajak daerah dan retribusi daerah berkonsultasi dengan Menteri dan selanjutnya Menteri berkoordinasi dengan menteri yang menyelenggarakan urusan pemerintahan bidang keuangan, dan untuk evaluasi rancangan Perda Kabupaten/Kota tentang tata ruang daerah berkonsultasi dengan Menteri dan selanjutnya Menteri berkoordinasi dengan menteri yang menyelenggarakan urusan pemerintahan bidang tata ruang.

5. Hasil evaluasi Rancangan Perda Provinsi dan rancangan Perda Kabupaten/Kota sebagaimana dimaksud pada ayat (1) dan ayat (3) jika disetujui diikuti dengan pemberian nomor register.

Berdasarkan Peraturan Menteri Dalam Negeri Nomor 80 Tahun 2015 terkait setiap rancangan Perda baik yang di evaluasi dan tidak di

${ }^{29}$ King Faisal Sulaiman, Politik Hukum Pengujian Peraturan Daerah Oleh Mahkamah Agung Dan Pemerintah Pasca Perubahan Undang-Undang Dasar Negara Republik Indonesia Tahun 1945, Disertasi Program Doktor (S-3) IImu Hukum Program Pascasarjana Universitas Islam Indonesia, Yogyakarta, 2016. HIm 214 
evaluasi dilakukan Pemberian nomor register sebelum ditetapkan oleh kepala daerah dan sebelum diundangkan dalam lembaran negara yaitu didalam Pasal 100 ayat (1) dan ayat (2) yang berbunyi:

1. Gubernur wajib menyampaikan rancangan Perda Provinsi kepada Menteri Dalam Negeri paling lama (tiga) hari terhitung sejak menerima rancangan perda provinsi dari pimpinan DPRD provinsi untuk mendaptkan noreg perda .

2. Bupati/walikota wajib menyampaikan rancangan Perda kabupaten/kota kepada Gubernur Sebagai Wakil Pemerintah Pusat paling lama 3 (tiga) hari terhitung sejak menerima rancangan perda kabupaten/kota dari pimpinan DPRD kabupaten/kota untuk mendapatkan noreg perda.

Setelah rancangan perda lolos dari instrumen eksekutif preview, kepala daerah melakukan pengesahan menjadi perda. Ketika telah ditetapkan menjadi perda, pengawasan yang bermaksud melihat kesesuaian materi perda dengan peraturan perundang-undangan yang lebih tinggi dilakukan secara represif oleh Mahkamah Agung dengan instrumen yudicial review. ${ }^{30}$

Kewenangan DPD yang baru sebagaimana diatur Pasal 249 ayat (1) huruf j Undang-undang Nomor 2 Tahun 2018 tentang MD3 yaitu melakukan pemantauan dan evaluasi terhadap Rancangan Peraturan Daerah dan Peraturan Daerah. Untuk menindaklanjuti kewenangan yang baru ini DPD sudah membentuk Panitia Urusan Legislasi Daerah (PULD) yang dibentuk pada sidang paripurna DPD dan merupakan alat kelengkapan yang bersifat tetap. Dengan adanya PULD ini diharapkan dapat menimalisir Ranperda dan Perda yang bertentangan dengan Peraturan Perundang-undangan yang lebih tinggi. Kewenangan DPD yang baru ini merupakan bentuk pengawasan dan kontrol terhadap kebijakan daerah sebagaimana peran DPD sebagai representasi teritorial dan paling utama untuk memastikan bahwa Ranperda dan Perda yang dibuat sesuai dengan kebutuhan masyarakat.

Kewenangan DPD ini bersifat rekomendasi bukan membatalkan. Hal ini dimaknai bahwa peran DPD dalam mengawasi Rancangan Perda dan Perda bersifat rekomendasi, agar Pemerintah Daerah dapat meninjau kembali Perda maupun Raperda melalui instrumen perubahan atau pencabutan perda, jika memang bertentangan dengan peraturan perundang-undang yang lebih tinggi. Menurut Akhmad Muqowam Wakil Ketua DPD RI Periode 2014-2018 dalam pengujian Ranperda dan Perda pasca UU Nomor 2 Tahun 2018 standar pengujian yang dilakukan oleh DPD RI yaitu kesesuaian antara jenis, hirarki dan materi muatan,

\footnotetext{
${ }^{30}$ Umbu Rauta, Rekonstruksi Sistem Pengujian Rancangan Peraturan Daerah Dan Peraturan Daerah Sesuai Amanat Undang Undang Dasar Negara Republik Indonesia Tahun 1945, Disertasi Program Doktor IImu Hukum Fakultas Hukum Universitas Diponegoro Semarang 2015, HIm 12
} 
kejelasan rumusan, pemenuhan asas materi muatan, potensi disharmoni dan efektivitas implementasi. "Lingkup tugas DPD RI adalah melihat ketaatan dan kesesuaian proses penyusunan Raperda, serta melihat pelaksanaan Perda dan menilai dampak dan efektifitas Perda. ${ }^{31}$

Menurut penulis kewenangan DPD dalam melakukan pemantauan dan evaluasi ini merupakan bentuk dari fungsi pengawasan sehingga dalam pelaksanaan kewenangan ini titik fokus DPD adalah peraturan daerah sehingga tidak terjadi tumpang tindih dengan kewenangan Pemerintah Pusat. Sebagaimana Putusan Mahkamah Konstitusi Nomor 137/PUU-XIII/2015 dan Nomor 56/PUU-XIV/2016 hanya menghapus kewenangan Pemerintah Pusat untuk membatalkan Peraturan Daerah sedangkan untuk melakukan pengawasan rancangan peraturan daerah masih berwenang melakukan Eksekutif Preview nya. Kewenangan DPD yang baru ini hanya berupa rekomendasi bukan membatalkan karena yang berwenang membatalkan peraturan daerah adalah Mahkamah Agung sesuai dengan kewenangannya menguji Peraturan Perundangundangan dibawah Undang-undang terhadap Undang-undang melalui Judicial Review. Adapun rekomendasi ini diberikan DPD kepada:

1. Lembaga Swadaya Masyarakat

DPD tidak bisa memberikan rekomendasi secara langsung kepada mahkamah Agung untuk membatalkan peraturan daerah karena pembatalan peraturan daerah di mahkamah agung melalui proses Judicial Review dan harus ada pemohon keberatan atas berlakunya peraturan daerah sebagaimana diatur dalam Peraturan Mahkamah Agung Nomor 1 Tahun 2011 Tentang Hak Uji Materil Pasal 1 ayat (4) "Pemohon keberatan adalah kelompok masyarakat atau perorangan yang mengajukan permohonan keberatan kepada Mahkamah Agung atas berlakunya suatu Peraturan Perundang-undangan tingkat lebih rendah dari undangundang". Sehingga dengan adanya rekomendasi ke Lembaga Swadaya Masyarakat bisa mewakili masyarakat yang dirugikan haknya oleh Perda dan menduga Perda tersebut bertentangan dengan peraturan perundangundangan yang lebih tinggi untuk melakukan Judicial Review ke Mahkamah Agung.

2. Rekomendasi ke DPRD dan Kepala Daerah

Rekomendasi diberikan kepada DPRD dan Kepala Daerah untuk meninjau kembali peraturan daerah jika bertentangan dengan kepentingan umum, dan kesusilaan untuk dilakukan perubahan terhadap Perda tersebut.

Rekomendasi yang diberikan oleh DPD tidak bersifat mengikat adapun rekomendasi menurut Kamus Besar Bahasa Indonesia (KBBI) artinya saran yang menganjurkan. Jika PULD aktif melaksanakan

\footnotetext{
${ }^{31}$ www.dpd.go.id/berita-407-banyak-temuan-perda-bermasalah-dpd-riberwenang-mengevaluasi
} 
kinerjanya maka kewenangan ini akan menjadi efektif sehingga dapat meniminalisir Peraturan Daerah yang bermasalah. DPD hanya berwenang menilai peraturan daerah bertentangan dengan peraturan perundangundang yang lebih tinggi, kepentingan umum serta kesusilaan namun tidak memiliki kewenangan untuk mengeluarkan keputusan terkait pembatalan peraturan daerah. Kewenangan baru DPD ini ternyata sama dengan kewenangan lainnya yang sumir fungsi yang sumir ini berasal dari aturan dasar yang mengatur kewenangan DPD yaitu UUD NRI 1945 sehingga untuk memperkuat eksistensi lembaga DPD harus diadakan amandemen ke-5 UUD NRI 1945.

DPD menjadi penting kalau terjadi sesuatu yang akan jarang terjadi dan sifatnya insidental berdasarkan UUD 1945, yakni terjadinya Impeachment Presiden/Wapres yang prosesnya sampai ke MPR dan terjadi perubahan atas UUD. Dua hal tersebut akan diuraikan lebih lanjut berikut ini. DPD menjadi sangat penting jika terjadi proses Impeachment yang sampai ke MPR setelah DPR mengajukan (Impeachment I) ke MK dan MK telah memutus bahwa dakwaan DPR benar adanya. Jika putusan MK ini ditindak lanjuti oleh DPR dengan usul agar MPR bersidang untuk menentukan Presiden/Wapres diberhentikan atau tidak (Impeachment II), maka suara anggota-anggota DPD akan sangat turut menentukan. Seperti diketahui, untuk menjatuhkan Presiden melalui Impeachment di MPR, sidang MPR itu akan dihadiri oleh $3 / 4$ dari seluruh anggota MPR dan putusan tentang Impeachment (pemakzulan). Hanya dapat dilakukan jika sekurangnya $2 / 3$ dari yang hadir itu setuju Presiden diberhentikan. ${ }^{32}$

DPD juga akan sangat penting seperti diketahui usulan perubahan UUD 1945 menurut Pasal 37 apabila diajukan oleh sekurang-kurangnya 1/3 dari jumlah anggota MPR dengan menunjukkan dengan jelas bagian yang akan diusulkan untuk diubah disertai alasannya. Jika ada upaya politik ke arah itu, maka anggota-anggota DPD, jika mereka kompak akan menjadi penting dan turut menentukan apakah setuju atau tidak usul perubahan. Dalam praktik yang muncul akhir-akhir ini, semua anggota DPD malahan menjadi unsur utama dalam upaya mengusulkan amandemen kelima.

Selanjutnya jika syarat dukungan memenuhi syarat maka kembali anggota DPD menjadi penting baik untuk quorum persidangan yang harus dihadiri oleh sekurang-kurangnya $2 / 3$ dari jumlah anggota MPR maupun untuk syarat minimal jumlah suara guna mengambil putusan. Sebab, putusan untuk mengubah pasal-pasal UUD itu dilakukan dengan persetujuan sekurang-kurangnya lima puluh persen ditambah satu dari seluruh anggota MPR, bukan hanya dari jumlah yang hadir dalam persidangan. Hanya pada kedua peristiwa dan forum yang sangat

${ }^{32}$ Mahfud MD, Perdebatan Hukum Tata Negara Pasca Amandemen Konstitusi, Cet 2, PT Raja Grafindo Persada, Jakarta, 2011HIm72 
insidental itulah anggota-anggota DPD menjadi penting mengingat perannya yang akan sangat mempengaruhi quorum dan berbagai putusannya.

Dalam hal ini menurut penulis yang dimaksud DPD menjadi penting disini adalah ketika DPD berperan menjadi anggota MPR kewenangannya tidak terbatas sebagai contoh jika terjadi proses amandemen UUD 1945 maka DPD ikut mengajukan amandemen UUD 1945, ikut membahas amandemen UUD 1945 dan ikut melakukan persetujuan terhadap amandemen UUD 1945.

\section{Kesimpulan}

Secara substantif kehadiran DPD belum bisa dikatakan sebagai lembaga Legislatif kecuali sebagai suplementasi kelembagaan Legisatif. Dalam bidang legislasi DPD hanya sebagai co-legislator dan sifat tugasnya DPD hanya sebagai penunjang (Auxiallary) tugas konstitusional DPR. Dalam fungsi pengawasan dapat dikatakan bahwa keberadaan DPD bersifat utama karena memiliki kekuasaan penuh dalam melakukan pengawasan terhadap kinerja pemerintah meskipun DPD tidak dapat mengeksekusi langsung hasil dari pengawasan yang dilakukannya. Oleh karena itu, DPD dapat lebih berkonsentrasi dibidang pengawasan, sehingga keberadaannya dapat dirasakan efektivitasnya oleh masyarakat di daerah-daerah. Kewenangan DPD dalam melakukan pemantauan dan evaluasi Rancangan Peraturan Daerah dan Peraturan Daerah yang tertuang dalam Undang-undang Nomor 2 Tahun 2018 dalam Pasal 249 ayat (1) Huruf j adapun kewenangan itu berupa rekomendasi. Rekomendasi yang diberikan tidak bersifat mengikat. DPD hanya berwenang menilai peraturan daerah bertentangan dengan peraturan perundang-undang yang lebih tinggi, kepentingan umum serta kesusilaan namun tidak memiliki kewenangan untuk mengeluarkan keputusan terkait pembatalan peraturan daerah.

\section{Daftar Pustaka}

\section{A. Buku-buku}

Abdul Ghoffar, Perbandingan Kekuasaan Presiden Indonesia Setelah Perubahan UUD 1945 Dengan Delapan Negara Maju, Prenada Media Group, Jakarta, 2009

Abdy Yuhana, Sistem Ketatanegaraan Indonesia, Fokus Media, Bandung, 2013

Ellydar Chaidir, Sistem Pemerintahan Negara Republik Indonesia, Total Media, Yogyakarta, 2008 Hartati, Menatap Masa Depan Dewan Perwakilan Daerah, CV Trisar Mitra Utama,Jambi, 2018 Husnu Abadi, Dari Plagiat Sampai UIR Press, Pekanbaru, 2005

Ke Contempt Of Court, 
Jimly Asshidiqie, Pekembangan \& Konsolidasi Lembaga Negara Pasca Reformasi, Sinar Grafika, Jakarta, 2016

J.Kaloh, Mencari Bentuk Otonomi Daerah Suatu Solusi Dalam Menjawab Kebutuhan Lokal Dan Tantangan, Cet 2, PT Rineka Cipta, Jakarta 2007

Mahfud MD, Dasar \& Struktur Ketatanegaraan Indonesia, $\quad$ Cet 2, PT Rineka Cipta,Jakarta, 2001

\section{Perdebatan Hukum}

Amendemen Konstitusi,

Cet 2, PT Raja

Tata Negara Pasca

Persada, Jakarta, 2011

Maria Farida Indrati S, IImu Perundang-Undangan

Grafindo

Fungsi, Dan Materi Muatan,Cet 5, Kansisus, Yogyakarta, 2007

Patrialis Akbar, Lembaga-Lembaga Negara Menurut UUD NRI

Tahun 1945, Cet 2,Sinar Grafika, Jakarta, 2015

Prajudi Atmosudirjo, Hukum

Administrasi Negara, Cet 10, Ghalia Indonesia, Jakarta, 1994

Suratman, Metode Penelitian Hukum, Alfabeta, Bandung, 2014

Yusri Munaf, Konstitusi dan Kelembagaan Negara, Marpoyan Tujuh, Pekanbaru, 2014

Zainuddin Ali, Metode Penelitian Hukum, Cet 2, Sinar Grafika, Jakarta, 2014

B. Peraturan Perundang-undangan

Undang-Undang Dasar Negara Republik Indonesia Tahun 1945

Undang-Undang Nomor 2 Tahun 2018 Tentang Majelis Permusyawaratan Rakyat, Dewan Perwakilan Rakyat, Dewan Perwakilan Daerah Dan Dewan Perwakilan Rakyat Daerah

Undang-Undang Nomor 7 Tahun 2017 Tentang Pemilihan Umum

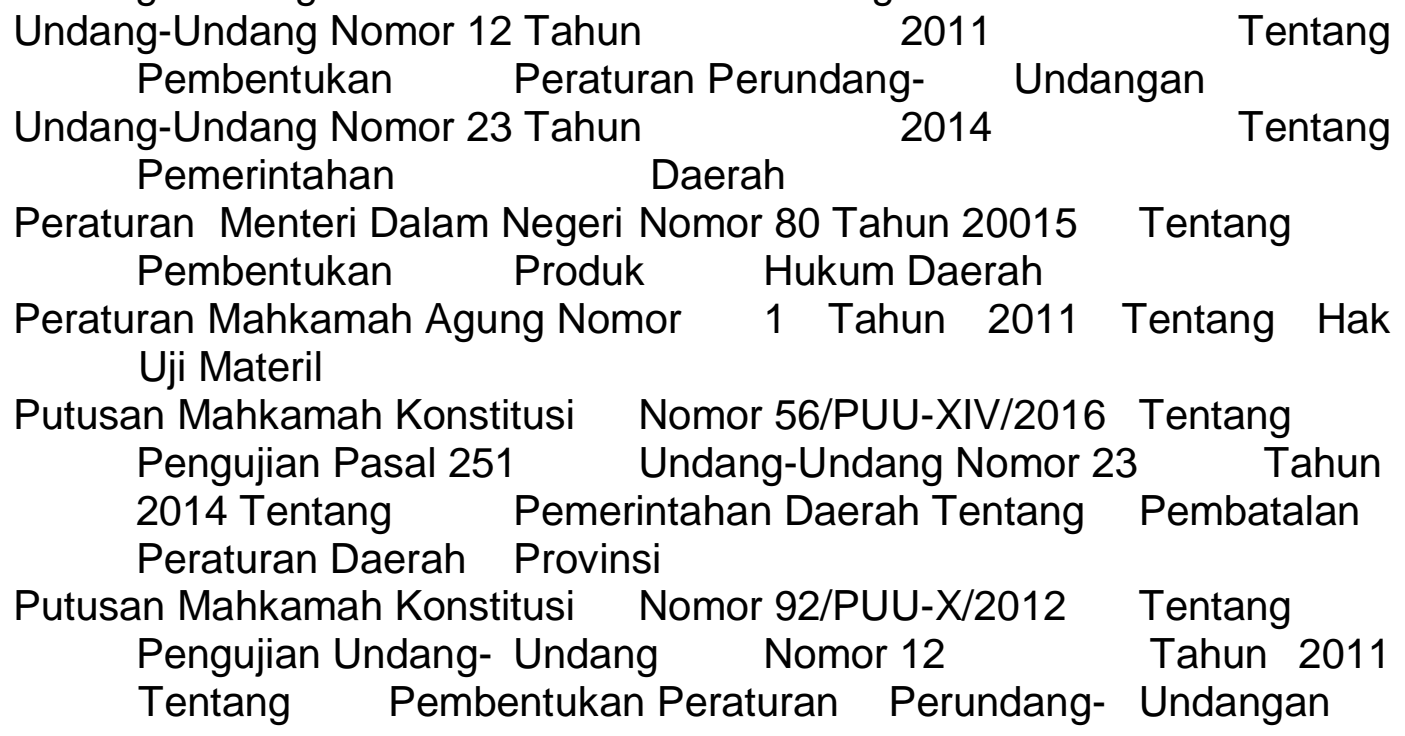


Dan Undang-Undang Nomor 17 Tahun 2014 Tentang MPR, DPR, DPD Dan DPRD Tentang Kedudukan DPD

Putusan Mahkamah Konstitusi Nomor 137/PUU-XIII/2015 Tentang

Pengujian Pasal 251 Undang-Undang Nomor 23

Tahun 2014 Tentang Pemerintahan Daerah

Tentang Pembatalan Perda Kabupaten/Kota

\section{Dan Lain-lain}

http://id.m.wikipedia.org/wiki/lembag

https://www.kompasiana.com/fathrah 4e2/dpdmenga wasi-perda

King Faisal Sulaiman, Politik Hukum Pengujian Peraturan Daerah

Oleh Mahkamah Agung Dan Pemerintah Pasca Perubahan Disertasi Program Doktor (S-3) Ilmu Hukum Program

Pascasarjana Universitas Islam Indonesia, Yogyakarta, 2016

Umbu Rauta, Rekonstruksi Sistem Pengujian Rancangan

Peraturan Daerah Dan Peraturan Daerah Sesuai

Amanat Undang Undang Dasar Negara Republik Indonesia

Tahun 1945, Disertasi Program Doktor IImu Hukum Fakultas

Hukum Universitas Diponegoro Semarang 2015

www.dpd.go.id/berita-407-banyak- temuan-perda-bermasalahdpd-ri-berwenang- mengevaluasi 